\title{
Lithospheric Flexural Isostasy Background of the 2017 Ms7.0 Jiuzhaigou Earthquake and Its Implications on Material Extrusion in the Northeastern Bayan Har Block
}

\section{Minzhang Hu ( $\nabla$ mzhhu@whu.edu.cn )}

Key Laboratory of Earthquake Geodesy, Institute of Seismology, China Earthquake Administration Yunlong Wu

Key Laboratory of Earthquake Geodesy, Institute of Seismology, China Earthquake Administration Hongtao Hao

Key Laboratory of Earthquake Geodesy, Institute of Seisnmology, China Earthquake Administraion Jiapei Wang

Key Laboratory of Earthquake Geodesy, Institute of Seismology, China Earthquake Administration Jian Wang

Key Laboratory of Earthquake Geodesy, Institute of Seismology, China Earthquake Administration Zhongya Li

Key Laboratory of Earthquake Geodesy, Institute of Seismology, China Earthquake Administration

Full paper

Keywords: Lithospheric flexural isostasy, Effective elastic thickness, Jiuzhaigou earthquake, tectonics

Posted Date: June 2nd, 2020

DOI: https://doi.org/10.21203/rs.3.rs-31019/v1

License: (c) (1) This work is licensed under a Creative Commons Attribution 4.0 International License. Read Full License

Version of Record: A version of this preprint was published at Tectonophysics on January $1 \mathrm{st}, 2022$. See the published version at https://doi.org/10.1016/j.tecto.2022.229209. 
1 Title: Lithospheric flexural isostasy background of the 2017 Ms7.0 Jiuzhaigou

2

3

4

5 Earthquake Administration, mzhhu@whu.edu.cn

6

7

8

9

10

11

\section{Har block}

"

Earthquake Administration, yunlongwu@whu.edu.cn

Earthquake Administration, haoht2004@ sina.com

Earthquake Administration, Wang_jia_pei@163.com

Earthquake Administration, kimyin447@163.com

Earthquake Administration, lzy56868@126.com

6

corresponding author: Minzhang Hu, mzhhu@whu.edu.cn

\section{earthquake and its implications on material extrusion in the northeastern Bayan}

Author \#1: Minzhang Hu, Key Laboratory of Earthquake Geodesy, Institute of Seismology, china

Author \#2: Yunlong Wu, Key Laboratory of Earthquake Geodesy, Institute of Seismology, china

Author \#3: Hongtao Hao, Key Laboratory of Earthquake Geodesy, Institute of Seismology, china

Author \#4: Jiapei Wang, Key Laboratory of Earthquake Geodesy, Institute of Seismology, china

Author \#5: Jian Wang, Key Laboratory of Earthquake Geodesy, Institute of Seismology, china

Author \#6: Zhongya Li, Key Laboratory of Earthquake Geodesy, Institute of Seismology, china 
Abstract: We applied a 2-dimensional, non-spectral technique to investigate the spatial variations of the lithospheric effective elastic thickness $\left(T_{e}\right)$ in the eastern Bayan Har block and its adjacent areas. $T_{e}$ values were determined by comparison of observed and flexural modelled Bouguer gravity anomalies. The results suggested that $T_{e}$ vary significantly from eastern Tibet to the Sichuan basin. The eastern Bayan Har block and northern Sichuan-Yunan block had low $T_{e}\left(0<T_{e}<20 \mathrm{~km}\right)$, indicated easily deformable lithosphere. The Sichuan basin had high $T_{e}\left(40 \mathrm{~km}<T_{e}<100 \mathrm{~km}\right)$, and acted as a rigid block which resisted the eastward extrusion of plateau materials. Moderate $T_{e}\left(30 \mathrm{~km}<T_{e}<40 \mathrm{~km}\right)$ under the Longmen Shan fault belt indicated that the lithosphere of the Sichuan basin plays an important role in supporting the Longmen Shan topography. The extremely low $T_{e}\left(T_{e}<10 \mathrm{~km}\right)$ in the seismogenic zone of the Ms7.0 Jiuzhaigou earthquake indicated that the topography is compensated locally, different from the Longmen Shan significantly. A banded relatively low $T_{e}(<40 \mathrm{~km})$ region stretched from northeastern Bayan Har block to southwestern Ordos block sketches out a plateau material escaping channel, questions the exiting of crustal flow in the north side of the Sichuan basin.

Keywords: Lithospheric flexural isostasy, Effective elastic thickness, Jiuzhaigou earthquake, tectonics

\section{Introduction}

On August 08, 2017, the Ms7.0 Jiuzhaigou earthquake stroke the northeastern margin of the Bayan Har block. The focal mechanism, distribution of relocated aftershocks and emergency field surveying indicate that the seismogenic fault is a sinistral fault located in the intersection area among the Tazang, Minjiang, and Huya faults (Xu et al., 2017; Liang et al., 2018; Nie et al., 2018; Liu et al., 2019). 


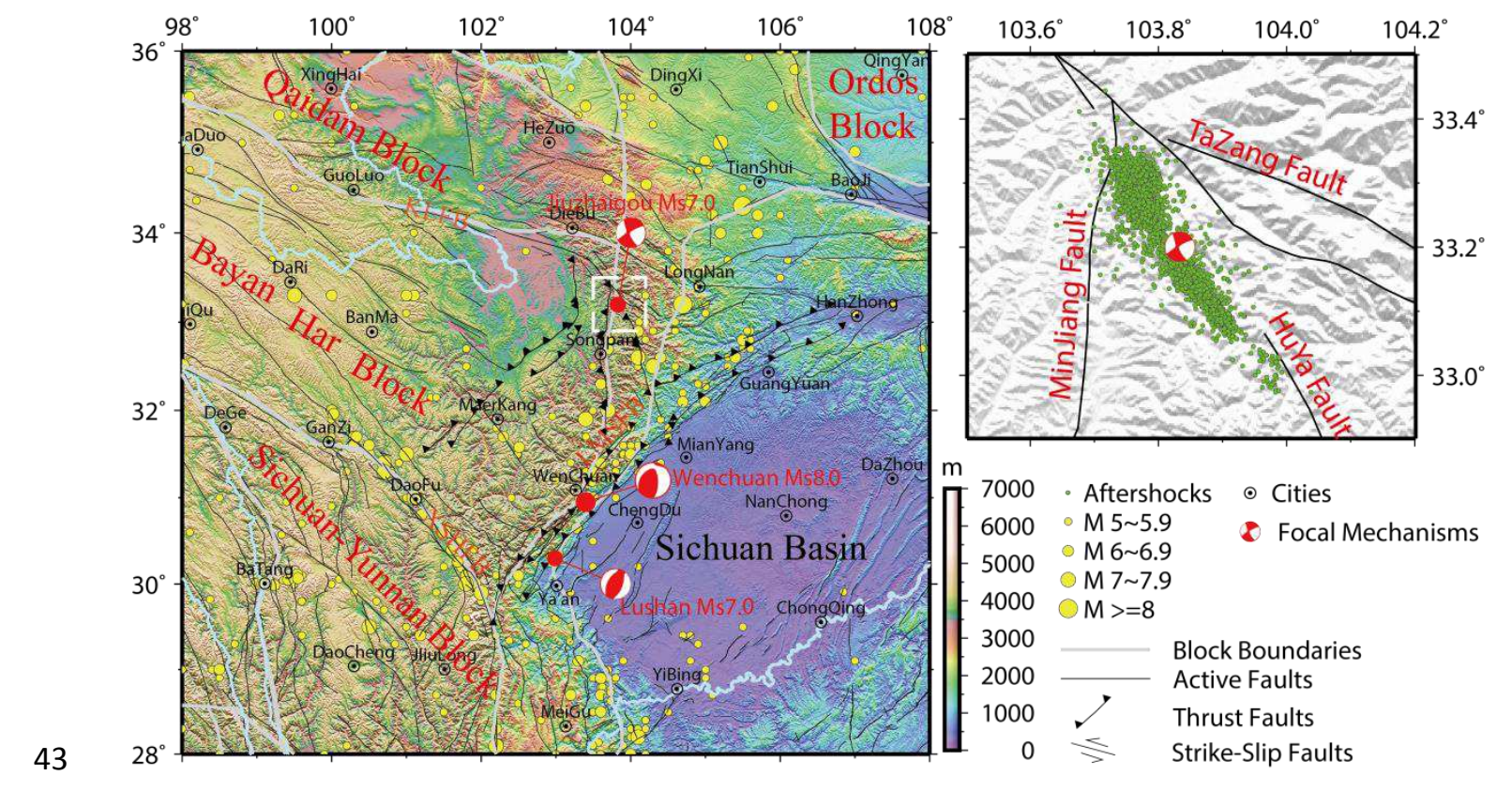

Fig.1 Tectonic settings and distribution of earthquakes in the studied area. The KLFB (Kunlun Fault Belt), LMSFB (Longmen Shan Fault Belt), and XSHFB (Xianshuihe Fault Belt) define the northern, eastern and southern boundaries of the Bayan Har block respectively. The relocated aftershocks (green dots) from Liang et al. (2018) describe the location of the seismogenic fault.

Many geodesy, geological and geophysical measurements have been used to explain the crustal deformation, material extrusion, and high seismicity of the eastern Bayan Har block. GPS observations show that the Qinghai-Tibet plateau is undergoing north-south compression and east-west materials extrusion (Wang et al., 2001; Zhang et al., 2004; Gan et al. 2007). The eastward crustal moving is inhibited by the rigid Sichuan basin, causing crustal thickening and uplifting in eastern Tibet (Liang et al., 2013; Hao et al., 2014). The Kunlun fault notes the north boundary of the Bayan Har block and plays an important role in accommodating Indo-Asian continental collision (Tapponnier and Molnar, 1976; Tapponnier, 2001). Geological surveys suggested that the left-lateral slip rates of the Kunlun fault decrease eastward systematic (Van der Woerd et al., 2000; Harkins et al., 2010; Ren et al., 2013). The 
Tazang, Minjiang and Huya faults belong to tail structures at the easternmost end of the Kunlun fault zone and absorbed the slip rates by thrusting, shortening, uplifting and regional rotation. Seismological and magnetotelluric explorations have been conducted to investigate the lithosphere structure and materials extrusion mode of the Qinghai-Tibet plateau (Wang et al., 2015; Wang et al., 2017). Some mechanisms of materials eastward extrusion have been proposed (Tapponnier and Molnar, 1976; Replumaz and Tapponnier, 2003; Royden et al., 1997, 2008; Klemperer, 2006), but the definite mode is still subject to debate.

It is supposed that the lateral lithosphere strength variations play an important role in the tectonic process of the eastern Qinghai-Tibetan plateau (Clark and Royden, 2000; Clark et al., 2005; Cook and Royden, 2008). For example, eastward-moving of the deformable Bayan Har block lithosphere is resisted by the rigid Sichuan basin, causing uplift of the Longmen Shan and accumulates stress on faults, which may generate strong earthquakes. The effective elastic thickness $\left(T_{e}\right)$ is a proxy of the lithosphere strength. Some researchers have estimated the $T_{e}$ on the Qinghai-Tibetan plateau based on the admittance/coherence spectral techniques or forward modelling methods (Braitenberg et al., 2003; Jordan and Watts, 2005; Chen et al., 2013). There have been few studies involve the details of $T_{e}$ distribution in eastern Bayan Har block and its adjacent areas, and mainly focus on the Longmen Shan ridge (Jiang and Jin, 2005; Fielding and McKenzie, 2012).

In this paper, we estimate $T_{e}$ in the focal area of the Ms7.0 Jiuzhaigou earthquake, including the eastern Bayan Har block, based on flexural isostasy analysis of gravity and topography data (Watts, 2001), by 2-dimensional, non-spectral method (Jordan and Watts, 2005). Based on a simple plate model, the Moho flexure loading by the topography is calculated by the finite difference method (Van Wees and Cloetingh, 
1994). The Bouguer gravity anomalies from the flexed Moho are calculated, and then the most suitable $T_{e}$ values were determined by comparison of the calculated and observed Bouguer gravity anomalies. Subsequently, combining $T_{e}$ with other geophysical data, we discussed the lithospheric isostasy background of the Ms7.0 Jiuzhaigou earthquake and the possible status of materials escaping in the northeastern Bayan Har block.

\section{Theory and method}

According to the lithosphere flexural isostasy model, the lithosphere can be described by a simple plate model, which has an elastic plate that lays over a fluid asthenosphere (Watts, 2001). The flexure of the lithosphere can be depicted by Moho undulations. The lithospheric flexure loading under the topography can be presented by differential equation (van Wees and Cloetingh, 1994),

$\mathrm{D} \frac{\partial^{4} \mathrm{w}}{\partial \mathrm{x}^{4}}+\mathrm{D} \frac{\partial^{4} \mathrm{w}}{\partial \mathrm{y}^{4}}+2 \mathrm{D} \frac{\partial^{4} \mathrm{w}}{\partial \mathrm{x}^{2} \partial \mathrm{y}^{2}}+2 \frac{\partial \mathrm{D}}{\partial \mathrm{x}} \frac{\partial^{3} \mathrm{w}}{\partial \mathrm{x}^{3}}+\frac{\partial^{2} \mathrm{D}}{\partial \mathrm{x}^{2}} \frac{\partial^{2} \mathrm{w}}{\partial \mathrm{x}^{2}}+2 \frac{\partial \mathrm{D}}{\partial \mathrm{y}} \frac{\partial^{3} \mathrm{w}}{\partial \mathrm{y}^{3}}+\frac{\partial^{2} \mathrm{D}}{\partial \mathrm{y}^{2}} \frac{\partial^{2} \mathrm{w}}{\partial \mathrm{y}^{2}}$

$+v \frac{\partial^{2} \mathrm{D}}{\partial \mathrm{y}^{2}} \frac{\partial^{2} \mathrm{w}}{\partial \mathrm{x}^{2}}+v \frac{\partial^{2} \mathrm{D}}{\partial \mathrm{x}^{2}} \frac{\partial^{2} \mathrm{w}}{\partial \mathrm{y}^{2}}+2 \frac{\partial \mathrm{D}}{\partial \mathrm{x}} \frac{\partial^{3} \mathrm{w}}{\partial \mathrm{x} \partial \mathrm{y}^{2}}+2 \frac{\partial \mathrm{D}}{\partial \mathrm{y}} \frac{\partial^{3} \mathrm{w}}{\partial \mathrm{x}^{2} \partial \mathrm{y}}+2(1-v) \frac{\partial^{2} \mathrm{D}}{\partial \mathrm{x} \partial \mathrm{y}} \frac{\partial^{2} \mathrm{w}}{\partial \mathrm{x} \partial \mathrm{y}}$

$=\mathrm{q}+\mathrm{d} \rho \mathrm{gw}+\sigma_{\mathrm{xx}} T_{e} \frac{\partial^{2} \mathrm{w}}{\partial \mathrm{x}^{2}}+\sigma_{\mathrm{yy}} T_{e} \frac{\partial^{2} \mathrm{w}}{\partial \mathrm{y}^{2}}+2 \sigma_{\mathrm{xy}} T_{e} \frac{\partial^{2} \mathrm{w}}{\partial \mathrm{x} \partial \mathrm{y}}$

where the lithospheric flexural rigidity $\mathrm{D}=E T_{e}^{3} / 12\left(1-v^{2}\right), E$ is Young's modulus, $v$ is Poisson's ratio, $\mathrm{w}$ is the lithospheric flexure (depicted by the flexed Moho), the topography loading $\mathrm{q}=\rho_{\mathrm{c}} \mathrm{g} h, \rho_{c}$ is the crustal density, $h$ is topography elevation, $\mathrm{g}$ is gravitational acceleration, $\rho_{m}$ is the mantle density, $\rho_{i n}$ is the density of the filled materials, $d \rho=\rho_{\text {in }}-\rho_{m},\left(\sigma_{\mathrm{xx}}, \sigma_{\mathrm{yy}}, \sigma_{\mathrm{xy}}\right)$ are components of the lateral tectonic stress.

Table 1 Mean Crustal parameters used in this paper

\begin{tabular}{lll}
\hline Parameter & Notation & Value
\end{tabular}




\begin{tabular}{lcc}
\hline Density of mantle & $\rho_{m}$ & $3270 \mathrm{~kg} / \mathrm{m}^{3}$ \\
Density of crust & $\rho_{c}$ & $2670 \mathrm{~kg} / \mathrm{m}^{3}$ \\
Density of the filled materials & $\rho_{i n}$ & $2670 \mathrm{~kg} / \mathrm{m}^{3}$ \\
Mean crustal thickness & $T_{c}$ & $30000 \mathrm{~m}$ \\
Young's modulus & $E$ & $10^{11} \mathrm{~N} / \mathrm{m}^{2}$ \\
Poisson's ratio & $v$ & 0.25 \\
Gravitational acceleration & $\mathrm{g}$ & $9.81 \mathrm{~m} / \mathrm{s}^{2}$ \\
\hline
\end{tabular}

If $T_{e}$ is assumed to be constant in the analysis window, Eq.(1) can be solved in the frequency domain, and then $T_{e}$ can be estimated by the admittance/coherence spectral techniques (Watts, 2001; Kirby, et al., 2014). In our study, the finite difference method was used to solve Eq.(1), which can take into account the lateral variation of $T_{e}$ in the analysis window. Replacing the partial differential formulas using the central difference formulas, the Eq.(1) can be transformed into linear equations,

$$
\mathrm{AW}=\mathrm{H}
$$

115 where

$$
\mathrm{W}=\left(\mathrm{w}_{1}, \mathrm{w}_{2}, \cdots \mathrm{w}_{\mathrm{i}} \cdots \mathrm{w}_{\mathrm{MN}-1}, \mathrm{w}_{\mathrm{MN}}\right)^{\mathrm{T}}
$$

and

$\mathrm{H}=\mathrm{C}_{2}\left(h_{1}, h_{2}, \cdots h_{i} \cdots h_{M N-1}, h_{M N}\right)^{\mathrm{T}}$ are column vectors, $\mathrm{C}_{2}=\frac{\rho_{c} \mathrm{~g}}{\mathrm{D}} \mathrm{dx}{ }^{4}$, and $\mathrm{A}$ is a

$\mathrm{MN} \times \mathrm{MN}$ diagonal sparse matrix.

For example, a Gaussian-type mountain with elevation of $2 \mathrm{~km}$ in the center loading on an elastic plate with variable $T_{e}$ will introduce Moho flexure, as shown in Fig.2. The Moho flexure (W) is obtained by solving the Eq.(2). The Bouguer gravity anomalies induced from the flexed Moho were calculated by Parker's formula (Parker, 122 1973). Then the most suitable $T_{e}$ value was determined by minimizing the root-mean-square (RMS) misfit between the calculated and observed Bouguer gravity anomalies. The iterative strategy proposed by Jordan and Watts (2005) was used to 

The absolute differences between the inputted and recovered $T_{e}$ are lower than $2 \mathrm{~km}$.

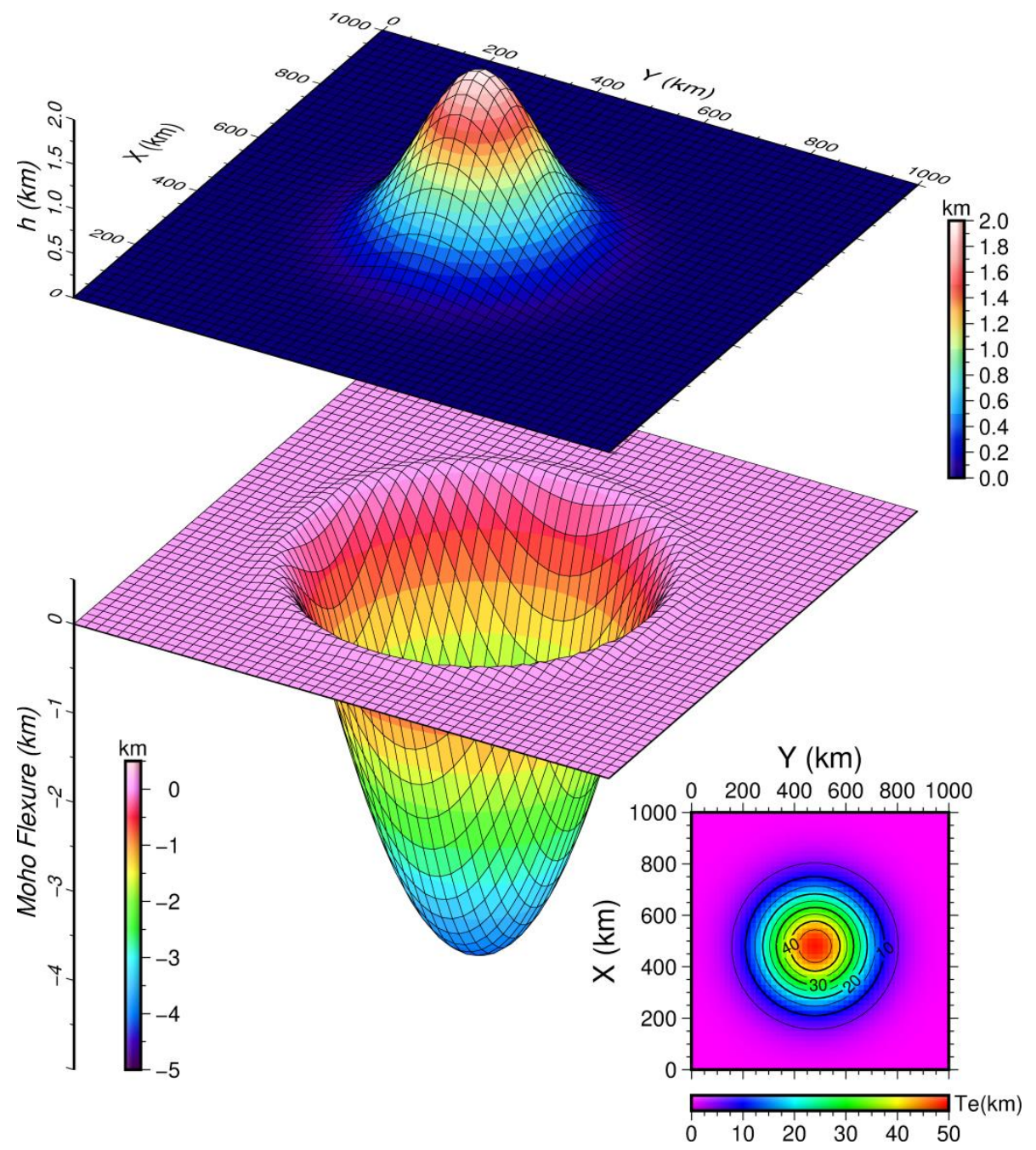

129 Fig.2 Modelled Gaussian-type mountain with elevation of $2 \mathrm{~km}$ in the center (upper)

130 loading on an elastic plate with variable Te (lower right corner), and the introduced

131 Moho flexure (lower). 
132
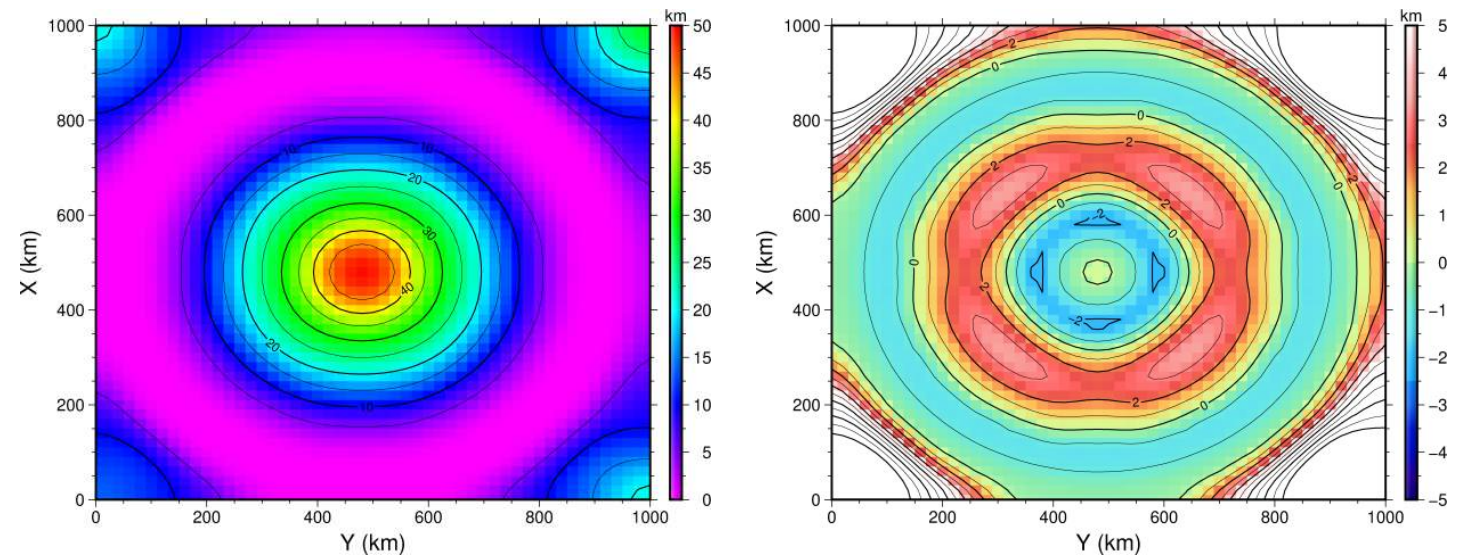

Fig. 3 The recovered Te structure (left) and the differences between the inputted and recovered Te (right). The results indicate that the Te structure can be recovered well in the center $200 \mathrm{~km} \times 200 \mathrm{~km}$ of the plate, and the absolute differences between the inputted and recovered Te are lower than $2 \mathrm{~km}$.

\section{Data and results}

Topography and gravity models were used to estimate $T_{e}$ in this study. The ETOPO1 global relief topography model downloaded from NCEI (National Centers for Environment Information) (Amante and Eakins, 2009) act as loading on the elastic plate, Fig.4. Simple Bouguer gravity anomalies were calculated from the EIGEN6C4 combined gravity model (Förste et al., 2014), using the online service of the ICGEM (International Center for Global Earth Models), Fig.5. The EIGEN6C4 model has higher quality than EGM2008 at wavelengths longer than $100 \mathrm{~km}$, for combining of the GOCE data. A 50km low-pass filter was applied to the downloaded simple Bouguer gravity anomalies, which will suppress the impact of local terrain fluctuation and unreliable short-wavelength fluctuations of the EIGEN6C4 model (Fielding and McKenzie, 2012). 


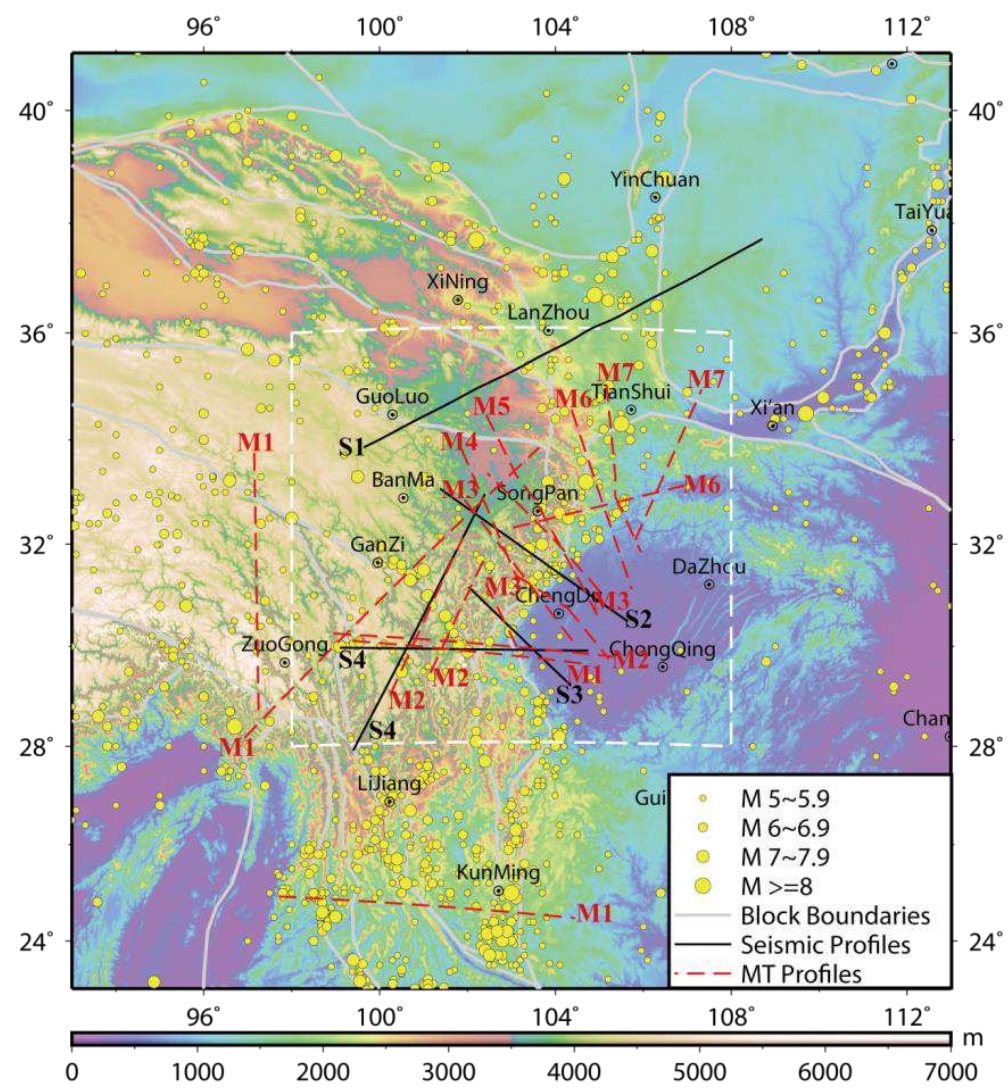

Fig.4 The topography from ETOPO1 in the studied area. $T_{e}$ was calculated in the white dashed box. S1 S4 are seismic surveying profiles. M1 M7 are magnetotelluric surveying profiles. S1: The Darlag-Lanzhoou-Jingbian seismic refraction profile across the northeastern Qinghai-Tibet Plateau (Liu et al., 2006), S2: The deep seismic wide-angle reflection/refraction profile stretched over the meizoseismal area of the Ms8.0 Wenchuan earthquake, on May 12, 2008 (Jia et al., 2014), S3: The high-resolution wide-angle reflection/refraction profile stretched over the epicentral area of the Ms7.0 Lushan earthquake, on April 20, 2013 (Wang et al., 2015), S4: The

159 deep seismic sounding profiles cross eastern margin of the plateau (Wang et al., 2007).

160 M1: The magnetotelluric profiles extend from the Qinghai-Tibet Plateau into southwest China (Bai et al., 2010), M2: The magnetotelluric sounding profiles from Sun et al.(2003), M3: The magnetotelluric profiles across the LMSFB (Zhao et al., 2012), M4: The Long-period magnetotelluric and broadband magnetotelluric sounding profile across the middle section of LMSFB (Wang et al., 2014), M5: The 


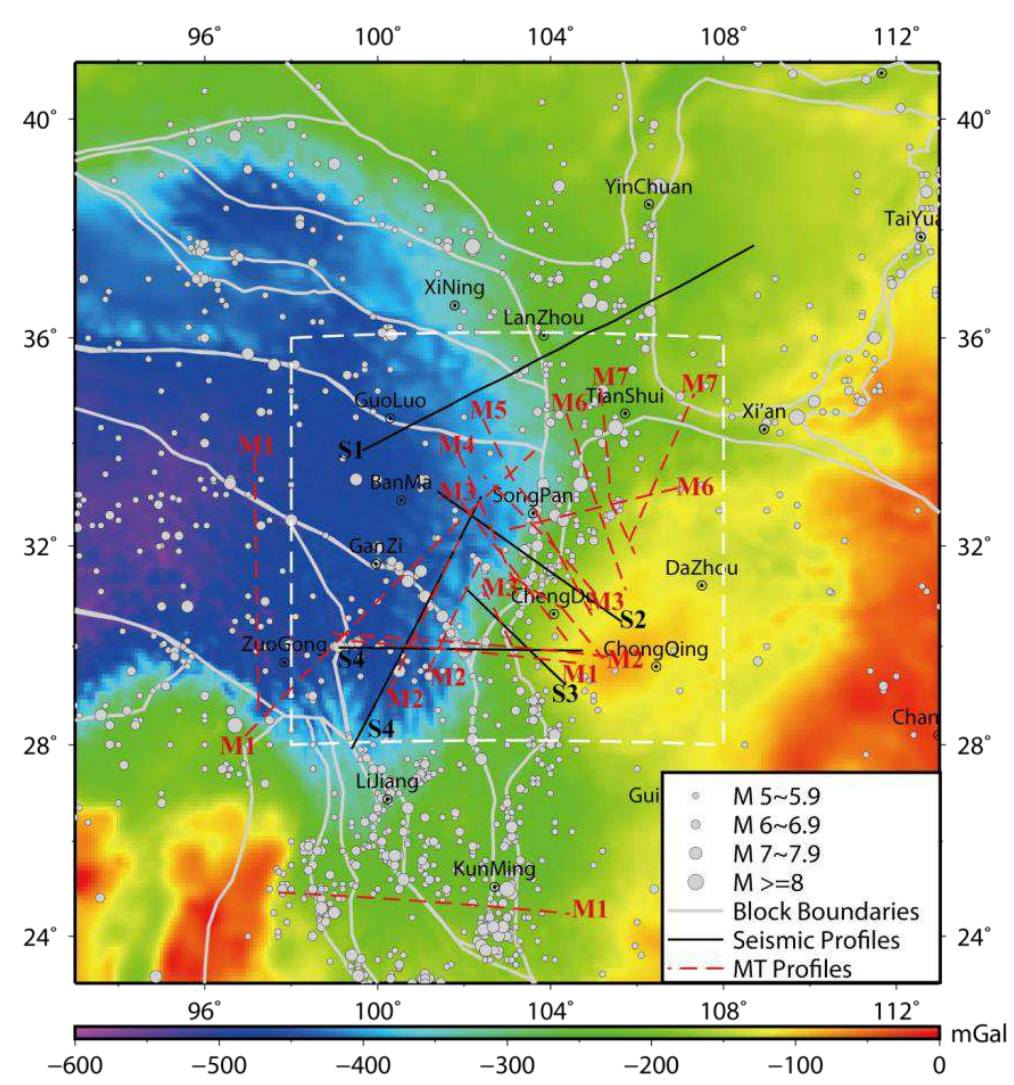

Fig.5 The Bouguer gravity anomalies from EIGEN6C4 in the studied area. S1 S4 are seismic surveying profiles, and M1 M7 are magnetotelluric surveying profiles, the same in Fig.4.

The recovered $T_{e}$ over the eastern Bayan Har block and its adjacent areas is shown in Fig.6(a), and the calculated Bouguer gravity anomalies are shown in Fig.6(b). Fig.6(a) shows that $T_{e}$ varies significantly from the eastern margin of the plateau to Sichuan basin. The eastern Bayan Har block and northern Sichuan-Yunan block has low lithospheric strength $\left(0<T_{e}<20 \mathrm{~km}\right)$, and the Sichuan basin, acts as a rigid block, has high $T_{e}\left(40<T_{e}<100 \mathrm{~km}\right)$.

The reliability of our $T_{e}$ structure can be evaluated by considering the crustal 179 isostatic status. Isostatic gravity anomalies are defined as differences between the 
observed Bouguer gravity anomalies and the effect of the compensation mass, and will be nearly zero if a suitable isostatic model is applied. Fig.6(c) shows that flexural isostatic gravity anomalies are generally subdued, and with amplitude lower than $20 \mathrm{mGal}$ in most of the studied region. For the Airy isostatic model, the topography is compensated locally, equivalent to flexural isostatic model with a $T_{e}$ of $0 \mathrm{~km}$. Fig.6(d) shows that Airy isostatic gravity anomalies are lower than $-40 \mathrm{mGal}$ in most of the studied region, which means that the Moho is deeper than predicted by Airy model. The most distinct feature of the Airy isostatic anomalies is the positive anomalies that correlate with the LMSFB. The flexural isostatic gravity anomalies (Fig.6(c)) have smaller amplitude than the Airy isostatic gravity anomalies (Fig.6(d)), and show no obvious anomaly features along the block boundaries, which mean that the flexural isostatic model (with variable $T_{e}$ ) is superior to Airy model in the studied area.
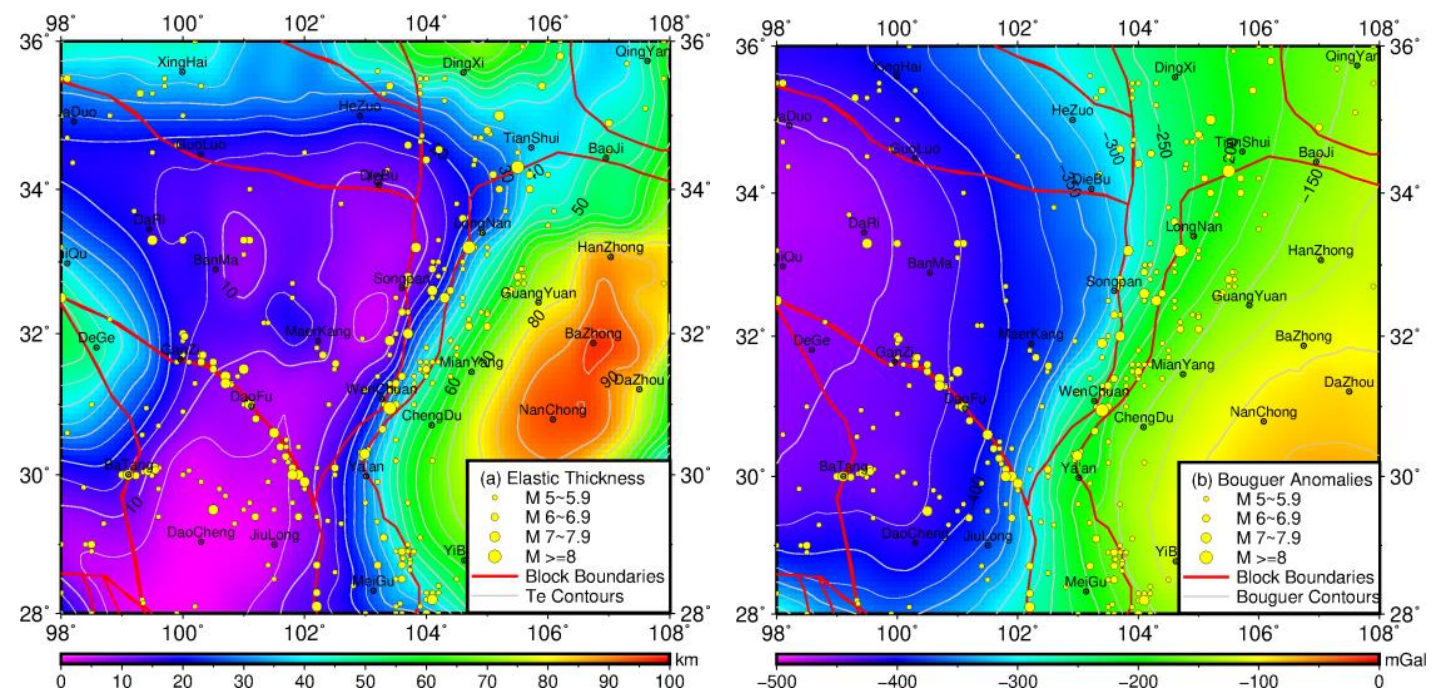

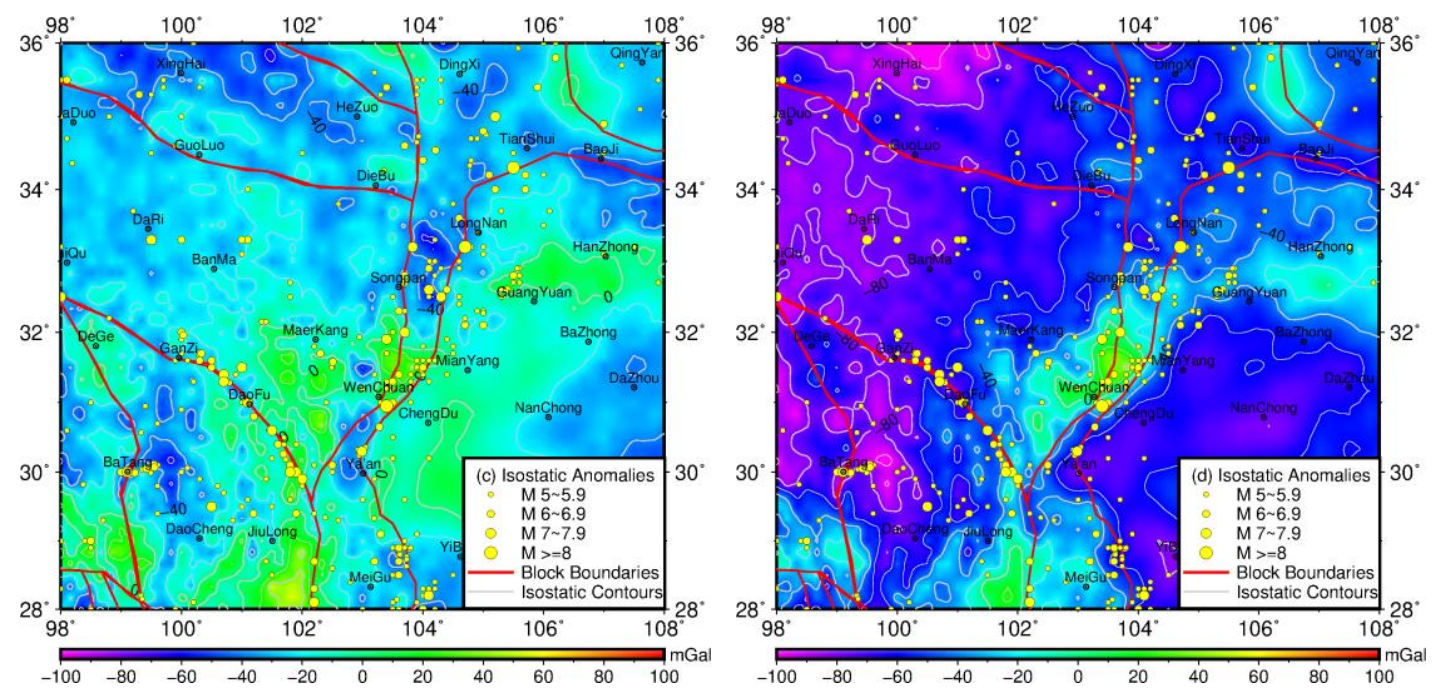

Fig.6 The recovered $T_{e}$ over the eastern Bayan Har block and its adjacent areas (a),

the calculated Bouguer anomalies (b), the flexural isostatic anomalies (c), and the

Airy isostatic anomalies (d).

Various authors have investigated the $T_{e}$ structure over the Qinghai-Tibet plateau and the Sichuan basin. Our estimate of low $T_{e}\left(0<T_{e}<20 \mathrm{~km}\right)$ in the eastern Tibet and high $T_{e}\left(40<T_{e}<100 \mathrm{~km}\right)$ in the Sichuan basin are consistent with some previous results. Braitenberg et al. (2003) suggested low $T_{e}$ of $10-30 \mathrm{~km}$ in most of the Tibetan Plateau, including values lower than $10 \mathrm{~km}$ in the eastern margin of the plateau. Yong et al. (2003) gave $T_{e}$ of $43-54 \mathrm{~km}$ in the foreland basin of Longmen Shan by stratigraphy analysis method. Jordan and Watts (2005) suggested a weak $\left(0<T_{e}<20 \mathrm{~km}\right)$ lithosphere region extends from the central plateau into south-western China, and $T_{e}$ is about $50 \mathrm{~km}$ in western Sichuan basin. Fielding and McKenzie (2012) estimated $T_{e}=54.6 \mathrm{~km}$ in the Sichuan basin by profile-fitting method, and $T_{e}=7 \mathrm{~km}$ in eastern Tibet by two-dimensional admittance analysis method. Chen et al. (2013) estimated variations of $T_{e}$ over China by multitaper coherence analysis of topography and Bouguer gravity anomalies. They suggested high $T_{e}(>60 \mathrm{~km})$ in the eastern Sichuan Basin, but low $T_{e}(10-40 \mathrm{~km})$ in the west and middle may be due to the dominated effect of the large topography of LMSFB. Jiang and Jin (2005) obtained 
variable $T_{e}$ of $36 \sim 45 \mathrm{~km}$, increasing from the eastern Bayan Har block to western Sichuan basin. This high $T_{e}$ value $\left(T_{e}=36 \mathrm{~km}\right)$ for eastern Bayan Har block is inconsistent with our results.

\section{Discussions}

Our $T_{e}$ structure revealed a dramatic difference of lithosphere strength from the eastern Tibet to the Sichuan basin. Low $T_{e}\left(0<T_{e}<20 \mathrm{~km}\right)$ region were recovered in eastern Tibet, indicates of long-term deformable lithosphere, correlate well with geodesy and geophysical studies. GPS-derived velocity field showed continuously crustal shortening and uplifting in eastern Tibet (Wang et al., 2001; Zhang et al., 2004; Liang et al., 2013). Seismic and magnetotelluric surveys found broadly distribution of low-velocity and high-conductivity zones in the mid-lower crust of the eastern Tibet (Wang et al., 2015; Wang et al., 2017a), may be due to partial melting of material which will weaken the lithosphere. $T_{e}$ of LMSFB have moderate values $(30-40 \mathrm{~km})$, suggested regionally compensation of the large topography. That means the lithosphere of western Sichuan basin plays an important role in supporting the Longmen Shan (Hubbard and Shaw, 2009). Magnetotelluric sounding profile suggested low-conductivity of the lithosphere under the Longmen Shan, that mean lithosphere of western Sichuan basin has wedged into the eastern edge of the Bayan Har block (Wang et al., 2014). The Sichuan basin is a high $T_{e}\left(40<T_{e}<100 \mathrm{~km}\right)$ region, similar to Tarim (110km), Qaidam (70km) basin (Braitenberg et al., 2003), and the Himalaya foreland (40 100km, Jordan and Watts, 2005). Given that the Sichuan basin has Precambrian basement (Ministry of Geology and Mineral Resources, 1991; Chen et al., 1994), high seismic wave velocity (Du et al., 2019), and relatively low heat flow (Jiang et al., 2019), the estimated high $T_{e}$ values are reasonable. The low $T_{e}$ in eastern Tibet and high $T_{e}$ in Sichuan basin revealed in this paper supports the view 
that eastward extrusion of the deformable plateau materials is resisted by the rigid Sichuan basin (Clark and Royden, 2000; Clark et al., 2005; Cook and Royden, 2008). The Ms7.0 Jiuzhaigou earthquake occurred in the northeastern of Bayan Har block, where has distinctly different isostatic status from LMSFB. Low $T_{e}(<20 \mathrm{~km})$ values are recovered in that region, and there are extremely low $T_{e}(<10 \mathrm{~km})$ in the seismogenic zone of the Jiuzhaigou earthquake, which means mechanically weak lithosphere consistent with seismic and magnetotelluric tomography results (Du et al., 2019; Riaz et al., 2019; Sun et al., 2020). The $T_{e}$ structure also suggested that there is a banded low $T_{e}(<40 \mathrm{~km})$ region stretched from the northeastern Bayan Har block to the southwestern Ordos block. This low $T_{e}$ region sketched out a deformable channel, which may support the escape of the plateau material, correlates well with the seismic low-velocity (Liu et al., 2006; Wang et al., 2007; Jia et al., 2014; Wang et al., 2015; Wang et al., 2017b) and high-conductivity zone (Wang et al., 2009; Zhao et al., 2012; Wang et al., 2014; Zhan et al., 2014; Min et al., 2017), Fig.7(a), questions the exiting of crustal flow in the north side of the Sichuan basin. The GPS velocity relative to Southeastern China (Dr. B. Zhao, personal communication) also directed to northeastern in the seismogenic zone, Fig.7(b). The eastward extrusion of materials along the Kunlun fault was not resisted by any rigid blocks in the east but absorbed by crustal thickening, rising, rotation and escaping. 


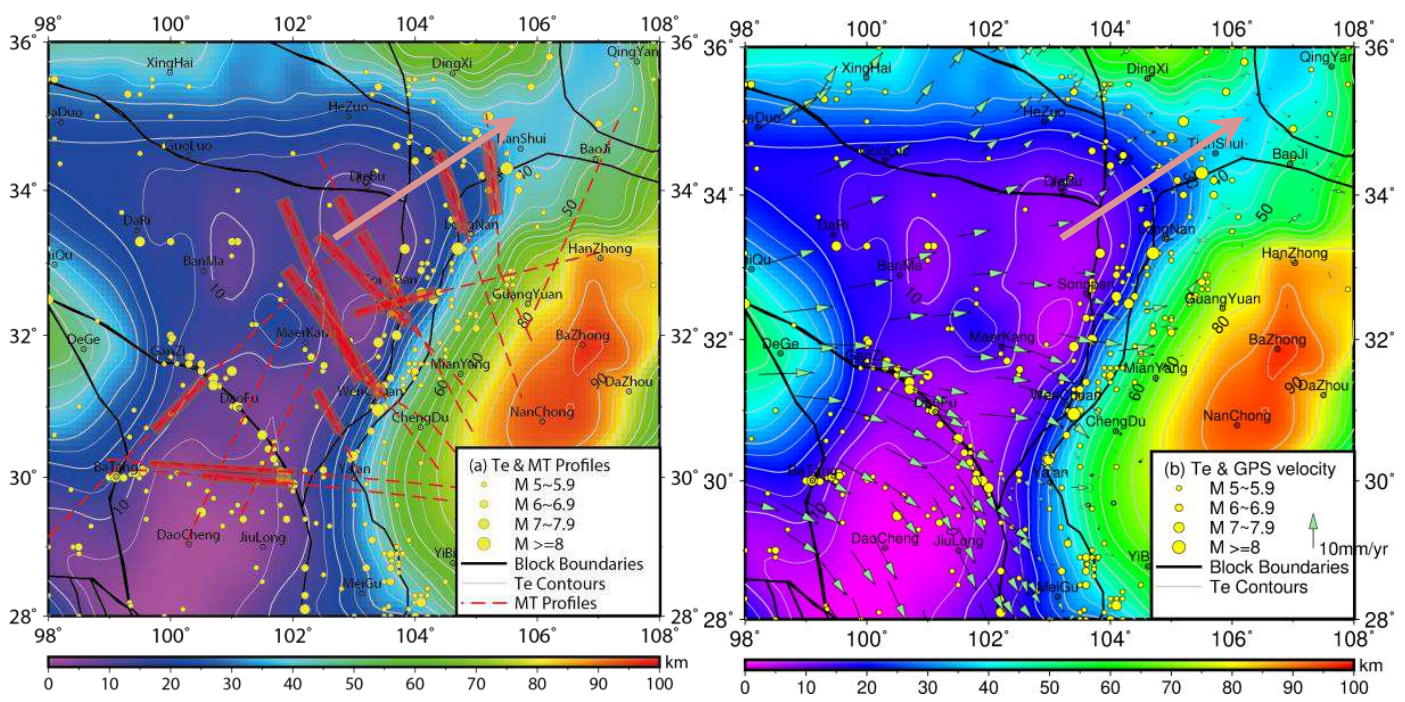

Fig.7 The recovered $T_{e}$ structure and distribution of the high-conductivity zones on

MT profiles (a). The red dashed lines show the same MT profiles in Fig.4. The red

shadows on MT profiles indicate high-conductivity zones. The relative low $T_{e}(<40 \mathrm{~km})$

region from the northeastern Bayan Har block to southwestern Ordos block correlates

well with the high-conductivity zones. The GPS velocity relative to Southeastern

China (Dr. B. Zhao, personal communication) also directed to northeastern in the seismogenic zone of the Ms7.0 Jiuzhaigou earthquake (b). The pink arrows indicate possible channel of material extrusion.

\section{Conclusions}

1. We revealed $T_{e}$ structure in the eastern Bayan Har block and its adjacent areas by 2-dimensional, non-spectral analysis of Bouguer gravity anomalies and topography data. The results suggested distinguishable lithosphere strength from eastern Tibet to Sichuan basin.

2. The eastern Tibet is a low $T_{e}\left(0<T_{e}<20 \mathrm{~km}\right)$ region, which means easily deformable

271 lithosphere of the plateau. The Sichuan basin has high $T_{e}\left(40<T_{e}<100 \mathrm{~km}\right)$, similar 272 to previous studies of the Tarim, Qaidam and Himalayan foreland basins, and acts as a rigid block which resisted the eastward extrusion of plateau materials. 
the lithosphere of the Sichuan basin may play an important role in supporting the thrusting Longmen Shan crust.

277

3. The seismogenic zone of the Ms7.0 Jiuzhaigou earthquake has extremely low $T_{e}$ $(<10 \mathrm{~km})$, and there is a banded low $T_{e}(<40 \mathrm{~km})$ region stretched from the northeastern Bayan Har block to the southwestern Ordos block. This low $T_{e}$ region may sketch out deformable materials escaping channel of the eastward extrusion plateau, questions the exiting of crustal flow in the north side of the Sichuan basin.

\section{Availability of data and materials}

The data that support the findings of this study are available upon reasonable request to Minzhang Hu. (email: mzhhu@whu.edu.cn)

\section{Abbreviations}

LMSFB: Longmen Shan Fault Belt; GPS: Global Positioning System; NCEI: National Centers for Environment Information; ICGEM: International Center for Global Earth Models.

\section{Authors' contributions}

Minzhang $\mathrm{Hu}$ calculated the $T_{e}$ and drafted the manuscript. Yunlong $\mathrm{Wu}$ tested the program and made the example in Fig.2 and Fig.3. Hongtao Hao analyzed the relationship between $T_{e}$ and seismic low-velocity zones. Jiapei Wang analyzed the relationship between $T_{e}$ and magnetotelluric high-conductivity zones. Jian Wang discussed the distribution of $T_{e}$ and its means to material extrusion of the plateau. Zhongya Li analyzed the relationship between $T_{e}$ and GPS velocity. All authors read and approved the final manuscript.

\section{Acknowledgements}

We are grateful to the NCEI and ICGEM for providing free topography and gravity model data. Generic Mapping Tools (GMTs) provided by Wessel and Smith(1998) were used to develop the figures. We are thankful to Dr. B. Zhao for providing GPS velocity data in Fig.7(b) and S.S. Liang for providing relocated aftershocks in Fig.1. We thank the anonymous reviewers and the editor for their helpful comments to 
improve our manuscript.

308

309

310

311

312

313

314

315

316

\section{Ethics approval and consent to participate}

Not applicable.

\section{Competing interests}

The authors declare that they have no competing interests.

\section{Funding}

This research was supported by the National Natural Science Foundation of China (Grant No.41974021, 41931074, 41974096), the Science for Earthquake Resilience of China Earthquake Administration (XH20039) and National Key R\&D Program of China (Grant No.2018YFC1503503-01).

\section{Publisher's Note}

Springer Nature remains neutral with regard to jurisdictional claims in published maps and institutional affiliations.

\section{References}

Amante C, Eakins BW. (2009) ETOPO1 1 Arc-minute Global Relief Model: Procedures, Data Sources and Analysis. NOAA Technical Memorandum NESDIS NGDC-24.

Bai DH, Unsworth MJ, Meju MA et al. 2010. Crustal deformation of the eastern Tibetan plateau revealed by magnetotelluric imaging. Nature Geoscience, 3(5): $358-362$.

Braitenberg C, Wang Y, Fang J et al. (2003) Spatial variations of flexure parameters over the Tibet-Qinghai plateau. Earth and Planetary Science Letters, 205(3-4): 
Chen B, Chen C, Kaban MK et al. (2013) Variations of the effective elastic thickness over China and surroundings and their relation to the lithosphere dynamics. Earth and Planetary Science Letters. 363: 61-72.

Chen SF, Wilson CJL, Luo ZL et al. (1994) The evolution of the Longmen Shan foreland basin. J. Southeast Asian Earth Sci, 10: 159-186.

Clark MK, Royden LH. (2000) Topographic ooze: building the eastern margin of Tibet by lower crustal flow. Geology, 28(8): 703-706.

Clark MK, Bush JWM, Royden LH. (2005) Dynamic topography produced by lower crustal flow against rheological strength heterogeneities bordering the Tibetan Plateau. Geophysical Journal International, 162(2): 575-590.

Cook KL, Royden LH. (2008) The role of crustal strength variations in shaping orogenic plateaus, with application to Tibet. Journal of Geophysical Research, 113(B08407), doi:10.1029/2007JB005457.

Du GB, Wu QJ, Zhang XM et al. (2019) Pn wave velocity and anisotropy underneath the central segment of the North-South Seismic Belt in China. Journal of Asian Earth Sciences. 184: 103941.

Fielding EJ, McKenzie D. (2012) Lithospheric flexure in the Sichuan Basin and Longmen Shan at the eastern edge of Tibet. Geophysical Research Letters, 39(9): L09311, doi: 10.1029/2012GL051680.

Förste C, Bruinsma SL, Abrikosov O et al. (2014) EIGEN-6C4: The latest combined global gravity field model including GOCE data up to degree and order 2190 of GFZ Potsdam and GRGS Toulouse. GFZ Data Services, doi: 10.5880/ICGEM.2015.1

Gan WJ, Zhang PZ, Shen ZK et al. (2007) Present-day crustal motion within the 
Tibetan Plateau inferred from GPS measurements. Journal of Geophysical Research: Solid Earth, 112(B8): B08416, doi: 10.1029/2005JB004120.

361

362

Hao M, Wang QL, Shen ZK et al. (2014) Present day crustal vertical movement inferred from precise leveling data in eastern margin of Tibetan plateau. Tectonophysics, 632: 281-292.

Harkins N, Kirby E, Shi X et al. (2010) Millennial slip rates along the eastern Kunlun fault: Implications for the dynamics of intracontinental deformation in Asia. Lithosphere, 2(4):247-266.

Hubbard J, Shaw JH et al. (2009) Uplift of the Longmen Shan and Tibetan plateau, and the 2008 Wenchuan $(M=7.9)$ earthquake. Nature, 458, doi:10.1038/nature07837.

Jia SX, Liu BJ, Xu ZF et al. (2014) The crustal structures of the central Longmenshan along and its margins as related to the seismotectonics of the 2008 Wenchuan Earthquake. Science China Earth Sciences, 57(4): 777-790.

Jiang GZ, Hu SB, Shi YZ et al. (2019) Terrestrial heat flow of continental China: Updated dataset and tectonic implications. Tectonophysics, 753: 36-48.

Jiang XD, Jin Y. (2005) Mapping the deep lithospheric structure beneath the eastern margin of the Tibetan Plateau from gravity anomalies. Journal of Geophysical Research, 110(B07407), doi:10.1029/2004JB003394.

Jordan TA, Watts AB. (2005) Gravity anomalies, flexure and the elastic thickness structure of the India-Eurasia collisional system. Earth and Planetary Science Letters, 236(3-4): 732-750.

Kirby JF. (2014) Estimation of the effective elastic thickness of the lithosphere using inverse spectral methods: the state of the art. Tectonophysics, 631: 87-116.

Klemperer S L. (2006) Crustal flow in Tibet: geophysical evidence for the physical 
state of Tibetan lithosphere, and inferred patterns of active flow. Geological Society, London, Special Publications, 268(1): 39.

Liang SM, Gan WJ, Shen CZ et al. (2013) Three-dimensional velocity field of present-day crustal motion of the Tibetan Plateau derived from GPS measurements. Journal of Geophysical Research: Solid Earth, 118(10): $5722-5732$.

Liang SS, Lei JS, Xu ZG et al. (2018) Relocation of aftershocks of the 2017 Jiuzhaigou, Sichuan, Ms7.0 earthquake and inversion for focal mechanism of the mainshock. Chin J Geophys. 61(5): 2163-2175. (in Chinese with English abstract)

Liu G, Xiong W, Wang Q et al. (2019) Source characteristics of the 2017 Ms7.0 Jiuzhaigou, China, earthquake and implications for recent seismicity in eastern Tibet. Journal of Geophysical Research: Solid Earth, 124. https://doi.org/10.1029/2018JB016340

Liu MJ, Mooney WD, Li SL et al. (2006) Crustal structure of the mortheastern margin of the Tibetan plateau from the Songpan-ganzi terrane to the Ordos basin. Tectonophysics, 420: 253-266.

Min G, Wang XB, Xia SB et al. (2017) Electrical structure of middle and upper crust beneath the Minshan uplift zone and central section of the West Qinling orogenic zone. Chin J Geophys. 60(6): 2397-2413. (in Chinese with English abstract)

Ministry of Geology and Mineral Resources (1991) Regional geology of Sichuan province, 728 pp., Geol. Publ. House, Beijing.

Nie ZS, Wang DJ, Jia ZG et al. (2018) Fault model of the 2017 Jiuzhaigou Mw6.5 earthquake estimated from coseismic deformation observed using Global Positioning System and Interferometric Synthetic Aperture Radar data. Earth, Planets and Space. 70:55, https://doi.org/10.1186/s40623-018-0826-4. 
Parker RL. (1973) The Rapid Calculation of Potential Anomalies. Geophys. J.R. Astr.Soc. 31: 447-455.

Ren JJ, Xu XW, Yeats RS et al. (2013) Latest quaternary paleoseismology and slip rates of the Longriba fault zone, eastern Tibet: Implications for fault behavior and strain partitioning. Tectonics, 32: 216-238.

Replumaz A, Tapponnier P. (2003) Reconstruction of the deformed collision zone between India and Asia by backward motion of lithospheric blocks. Journal of Geophysical Research: Solid Earth, 108(B6): 2285, doi: 10.1029/2001JB000661.

Riaz MS, Zheng Y, Liu F et al. (2019) Tomographic imaging of the 2017 Ms7.0 Jiuzhaigou earthquake source region and its implications on material extrusion in the northeast Tibetan plateau. Tectonophysics, 752:24-34.

Royden LH, Burchfiel BC, King RW et al. (1997) Surface deformation and lower crustal flow in eastern Tibet. Science, 276(5313): 788-790.

Royden LH, Burchfiel BC, Van Der Hilst RD. (2008) The Geological evolution of the Tibetan Plateau. Science, 321(5892): 1054-1058.

Sun J, Jin GW, Bai DH et al. (2003) Sounding of electrical structure of the crust and upper mantle along the eastern border of Qinghai-Tibet Plateau and its tectonic significance. Science in China (Series D), 46(Supp.): 243-253.

Sun XY, Zhan Y, Zhang HP et al. (2020) 3-D magnetotelluric imaging of the easternmost Kunlun fault: insights into strain partitioning and the seismotectonics of the Jiuzhaigou Ms7.0 earthquake. Journal of Geophysical Research: Solid Earth, doi:10.1029/2020JB019731.

Tapponnier P, Molnar P. (1976) Slip-line field theory and large-scale continental tectonics. Nature, 264(25): 319-324.

Tapponnier P, Xu ZQ, Roger F et al. (2001) Oblique stepwise rise and growth if the 
Van der Woerd J, Ryerson FJ, Tapponnier P et al. (2000) Uniform slip-rate along the Kunlun fault: Implications for seismic behavior and large-scale tectonics. Geophysical Research Letters, 27(16): 2353-2356.

Van Wees JD, Cloetingh S. (1994) A finite-difference technique to incorporate spatial variations in rigidity and planar faults into 3-D models for lithospheric flexure. Geophysical Journal International, 117(1): 179-195.

Wang CY, Han WB, Wu JP et al. (2007) Crustal structure beneath the eastern margin of the Tibetan Plateau and its tectonic implications. Journal of Geophysical Research, 112(B07307), doi:10.1029/2005JB003873.

Wang CY, Yang WC, Wu JP et al. (2015) Study on the lithospheric structure and earthquakes in North-South tectonic belt. Chin J Geophys. 58(11): 3867-3901, doi: 10.6038/cjg20151101. (in Chinese with English abstract)

Wang Q, Zhang PZ, Freymueller JT et al. (2001) Present-day crustal deformation in china constrained by global positioning system measurements. Science, 294(5542): 574-577.

Wang SJ, Wang FY, Zhang JS et al. (2015) The deep seismogenic environment of Lushan Ms7.0 earthquake zone revealed by a wide-angle reflection/refraction seismic profile. Chin J Geophys. 58(9): 3193-3204. (in Chinese with English abstract)

Wang XB, Zhu YT, Zhao XK et al. (2009) Deep conductivity characteristics of the Longmen Shan, eastern Qinghai-Tibet plateau. Chin J Geophys. 52(2): 564-571. (in Chinese with English abstract)

Wang XB, Zhang G, Fang H et al. (2014) Crust and upper mantle resistivity structure at middle section of Longmenshan, eastern Tibetan plateau. Tectonophysics, 
Wang XB, Yu N, Gao S et al. (2017a) Research progress in research on electrical

Watts AB. (2001) Isostasy and Flexure of the Lithosphere. Cambridge: Cambridge University Press.

Xu XW, Chen GH, Wang QX et al. (2017) Discussion on seismogenic structure of Jiuzhaigou earthquake and its implication for current strain state in the southeastern Qinghai-Tibet Plateau. Chin J Geophys. 60(10): 4018-4026. (in Chinese with English abstract)

Yong L, Allen PA, Densmore AL et al. (2003) Evolution of the Longmen Shan foreland basin (Western Sichuan, China) during the Late Triassic Indosinian Orogeny. Basin Research, 15: 117-138.

Zhao GZ, Unsworth MJ, Zhan Y et al. (2012) Crustal structure and rheology of the Longmenshan and Wenchuan Mw7.9 earthquake epicentral area from magnetotelluric data. 40(12): 1139-1142.

Zhan Y, Zhao GZ, Wang LF et al. (2014) Deep electric structure beneath the intersection area of West Qinling orogenic zone with North-South Seismic tectonic zone in China. Chin J Geophys. 57(8): 2594-2607. (in Chinese with English abstract)

Zhang PZ, Shen ZK, Wang M et al. (2004) Continuous deformation of the Tibetan plateau from global positioning system data. Geology, 32(9): 809-812. 


\section{Figures}

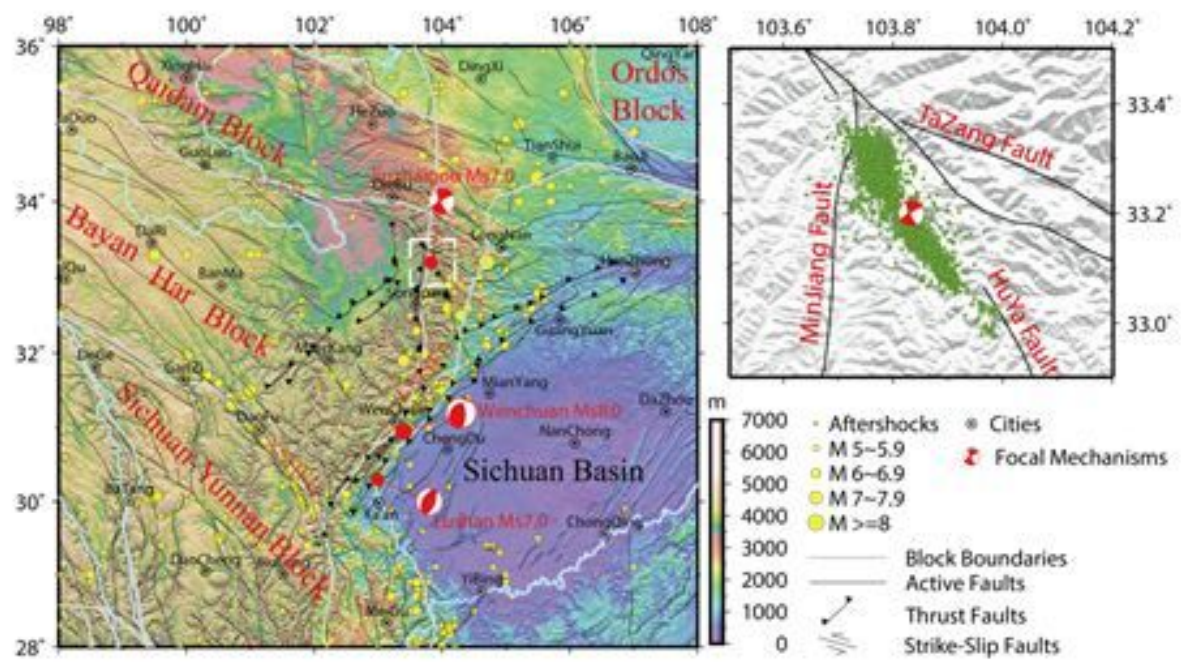

\section{Figure 1}

Tectonic settings and distribution of earthquakes in the studied area. The KLFB (Kunlun Fault Belt), LMSFB (Longmen Shan Fault Belt), and XSHFB (Xianshuihe Fault Belt) define the northern, eastern and southern boundaries of the Bayan Har block respectively. The relocated aftershocks (green dots) from Liang et al. (2018) describe the location of the seismogenic fault. 

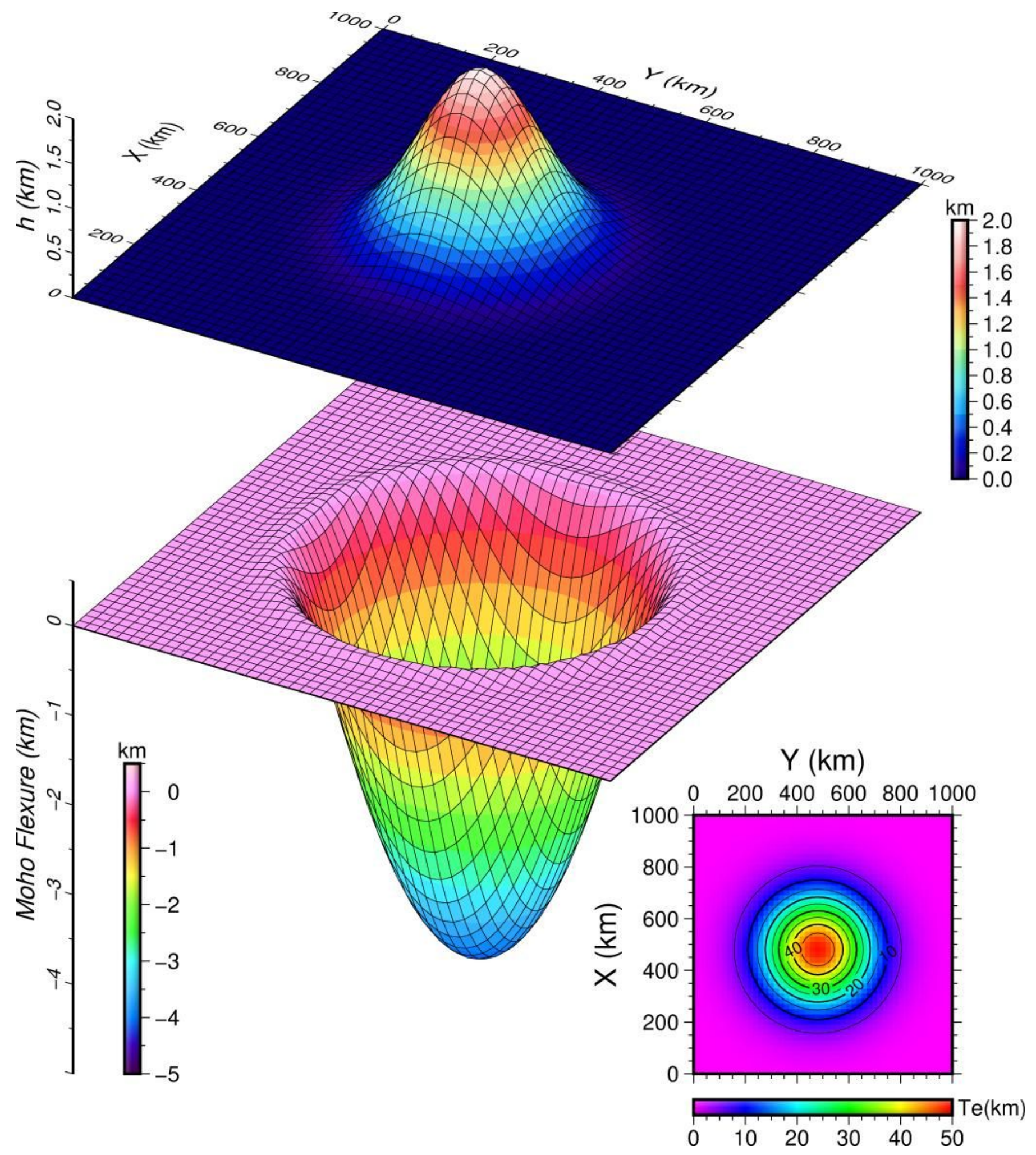

Figure 2

Modelled Gaussian-type mountain with elevation of $2 \mathrm{~km}$ in the center (upper) loading on an elastic plate with variable Te (lower right corner), and the introduced Moho flexure (lower). 

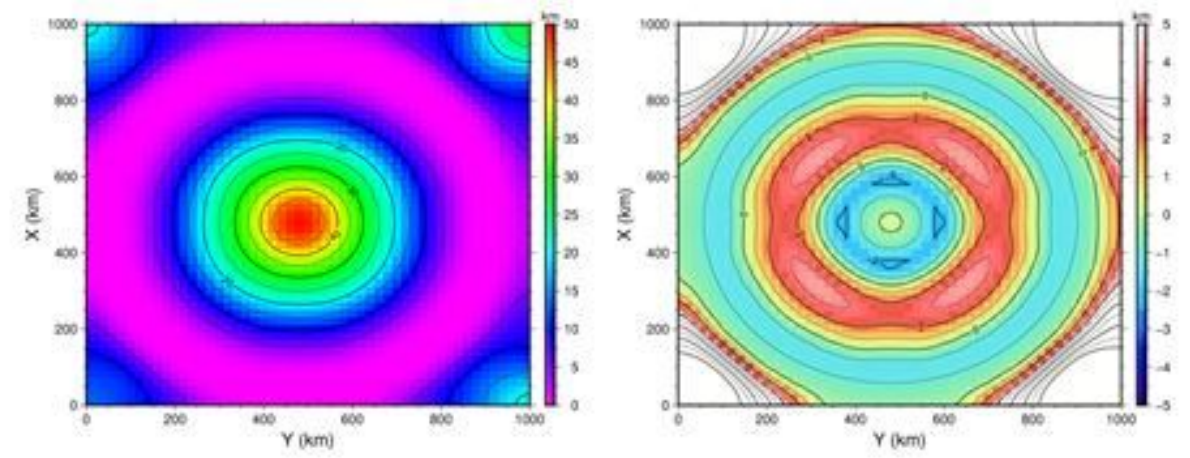

\section{Figure 3}

The recovered Te structure (left) and the differences between the inputted and recovered Te (right). The results indicate that the Te structure can be recovered well in the center $200 \mathrm{~km} \times 200 \mathrm{~km}$ of the plate, and the absolute differences between the inputted and recovered Te are lower than $2 \mathrm{~km}$.

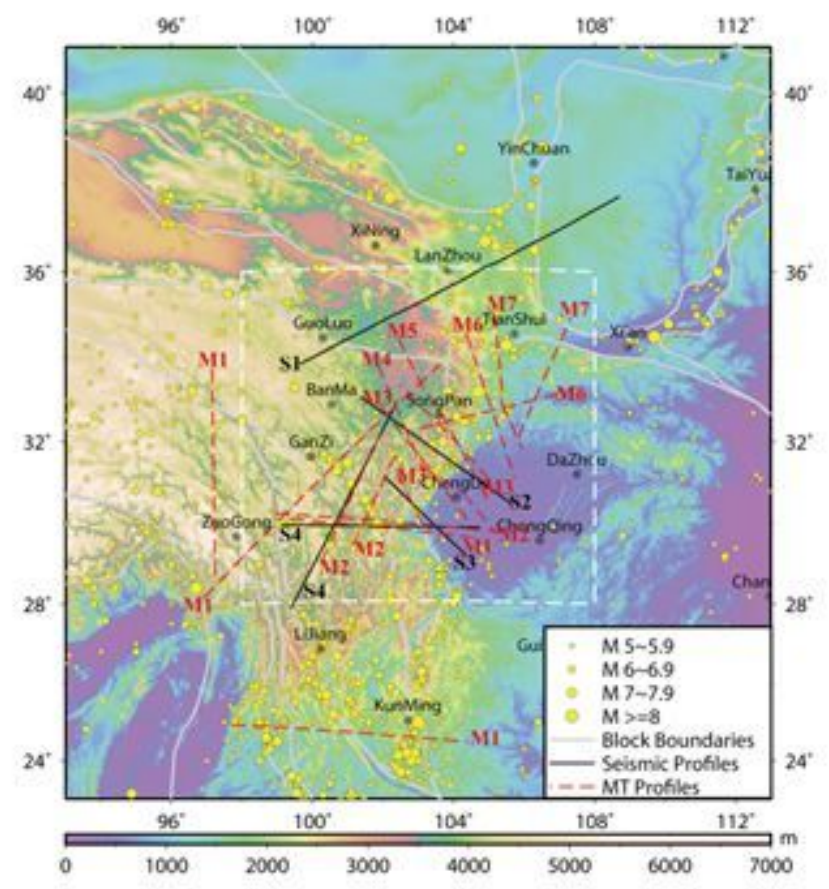

\section{Figure 4}

The topography from ETOPO1 in the studied area. Te was calculated in the white dashed box. S1 S4 are seismic surveying profiles. M1 M7 are magnetotelluric surveying profiles. S1: The Darlag-LanzhoouJingbian seismic refraction profile across the northeastern Qinghai-Tibet Plateau (Liu et al., 2006), S2: The deep seismic wide-angle reflection/refraction profile stretched over the meizoseismal area of the Ms8.0 Wenchuan earthquake, on May 12, 2008 (Jia et al., 2014), S3: The high-resolution wide-angle reflection/refraction profile stretched over the epicentral area of the Ms7.0 Lushan earthquake, on April 20, 2013 (Wang et al., 2015), S4: The deep seismic sounding profiles cross eastern margin of the plateau (Wang et al., 2007). M1: The magnetotelluric profiles extend from the Qinghai-Tibet Plateau into southwest China (Bai et al., 2010), M2: The magnetotelluric sounding profiles from Sun et al.(2003), M3: 
The magnetotelluric profiles across the LMSFB (Zhao et al., 2012), M4: The Long-period magnetotelluric and broadband magnetotelluric sounding profile across the middle section of LMSFB (Wang et al., 2014), M5: The Luqu-Zhongjiang magnetotelluric profile from Wang et al. (2009), M6: The magnetotelluric profiles from Min et al.(2017), M7: The magnetotelluric profiles from Zhan et al.(2014).

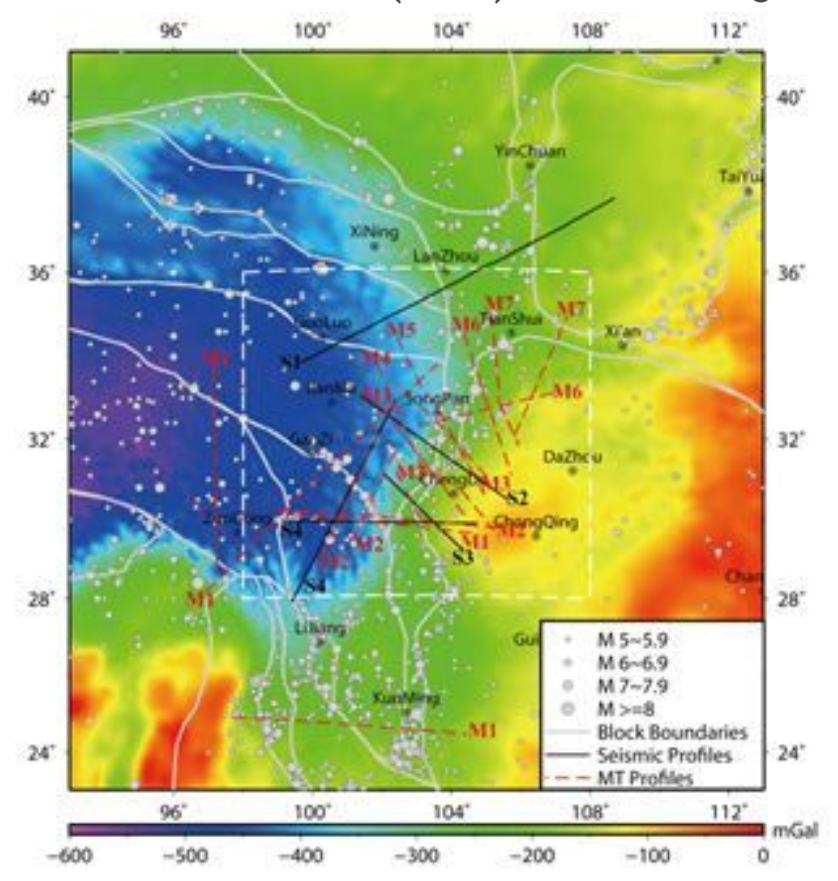

Figure 5

The Bouguer gravity anomalies from EIGEN6C4 in the studied area. S1 S4 are seismic surveying profiles, and M1 M7 are magnetotelluric surveying profiles, the same in Fig.4. 

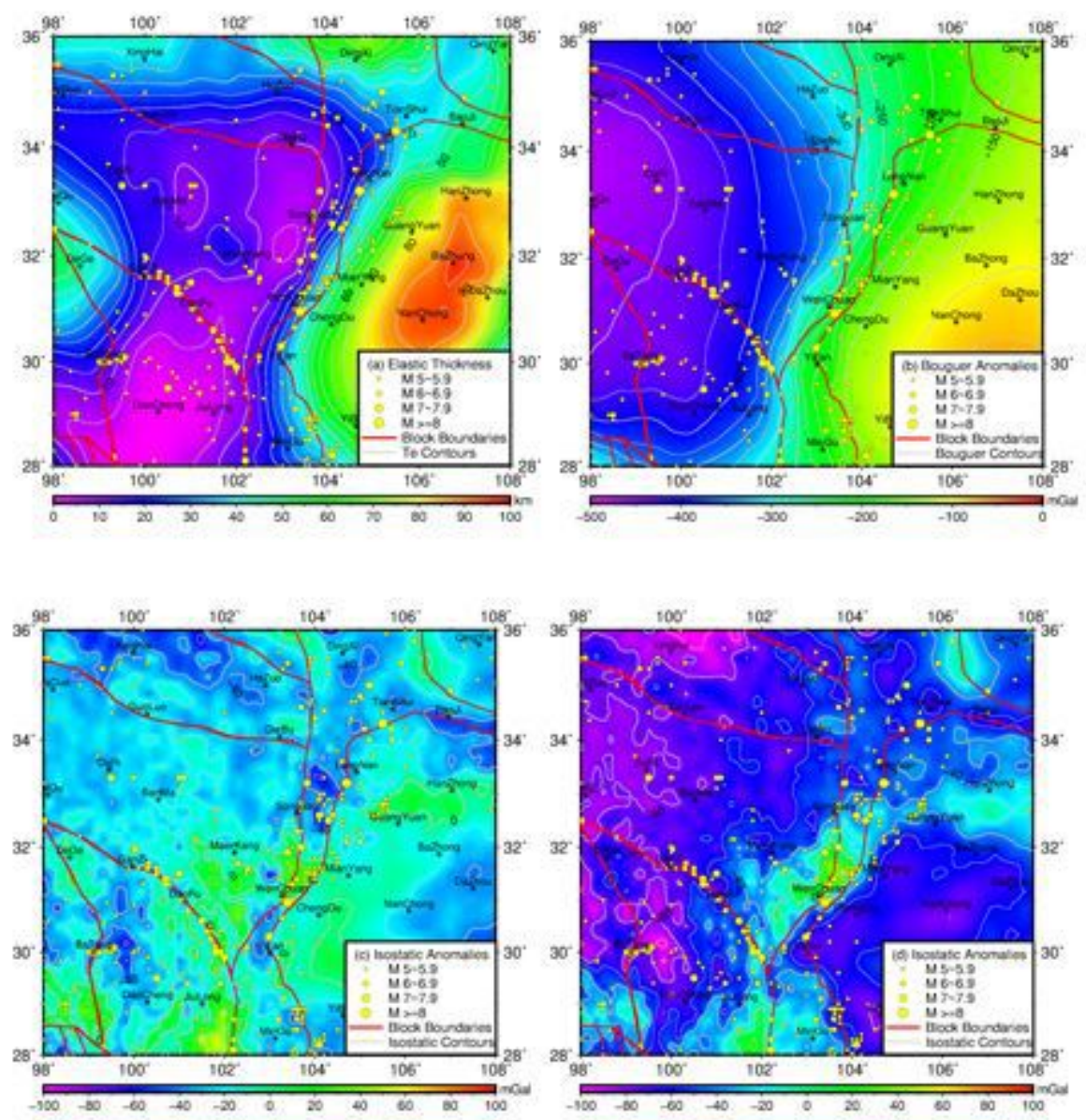

\section{Figure 6}

The recovered Te over the eastern Bayan Har block and its adjacent areas (a), the calculated Bouguer anomalies (b), the flexural isostatic anomalies (c), and the Airy isostatic anomalies (d).

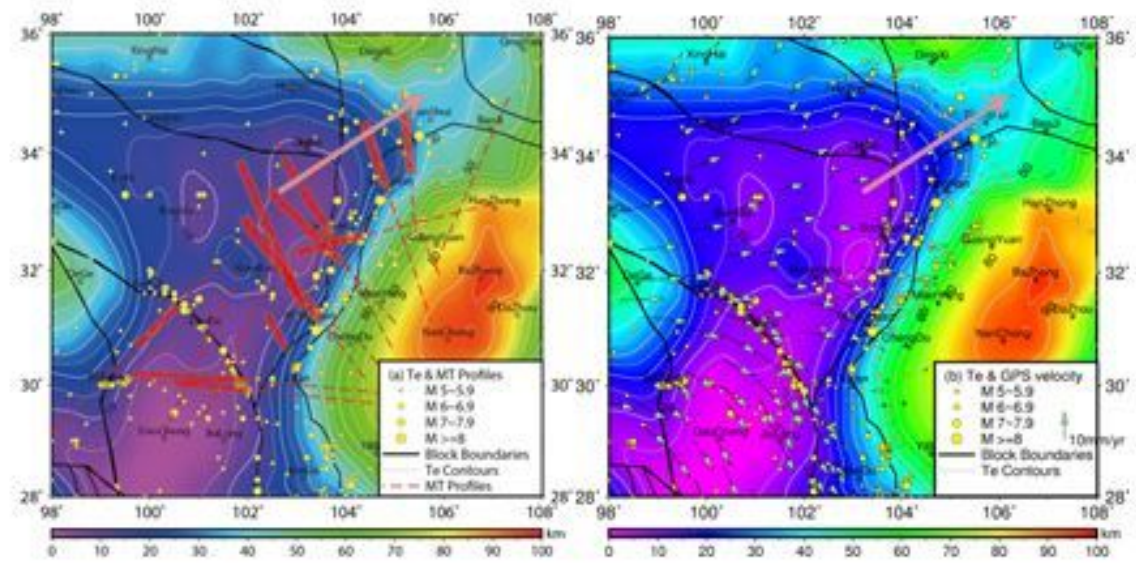

\section{Figure 7}

The recovered Te structure and distribution of the high-conductivity zones on MT profiles (a). The red dashed lines show the same MT profiles in Fig.4. The red shadows on MT profiles indicate high- 
conductivity zones. The relative low $\mathrm{Te}(<40 \mathrm{~km})$ region from the northeastern Bayan Har block to southwestern Ordos block correlates well with the high-conductivity zones. The GPS velocity relative to Southeastern China (Dr. B. Zhao, personal communication) also directed to northeastern in the seismogenic zone of the Ms7.0 Jiuzhaigou earthquake (b). The pink arrows indicate possible channel of material extrusion.

\section{Supplementary Files}

This is a list of supplementary files associated with this preprint. Click to download.

- GraphicalAbstract1.png

- GraphicalAbstract.svg 